\title{
Is there a role for tissue plasminogen activator as a novel treatment for refractory COVID-19 associated acute respiratory distress syndrome?
}

\author{
Hunter B. Moore, MD, PhD, Christopher D. Barrett, MD, Ernest E. Moore, MD, \\ Robert C. McIntyre, MD, Peter K. Moore, MD, Daniel S. Talmor, MD, \\ Frederick A. Moore, MD, and Michael B. Yaffe, MD, PhD, Boston, Massachusetts
}

$\mathrm{T}$ he global pandemic of COVID-19 has begun to oversaturate the world's medical capacity to accommodate a large surge of patients with acute respiratory distress syndrome (ARDS). ${ }^{1}$ Acute respiratory distress syndrome has no effective treatment besides supportive care, with the use of ventilatory strategies encompassing low tidal volumes that limit transpulmonary pressures being the mainstay. ${ }^{2}$ A consistent finding in ARDS is the deposition of fibrin in the airspaces and lung parenchyma, along with fibrin-platelet microthrombi in the pulmonary vasculature, which contribute to the development of progressive respiratory dysfunction and right heart failure. ${ }^{3-5}$ Similar pathologic findings have now been observed in lung specimens from patients infected with COVID-19. ${ }^{6}$ This physiologically destructive activation of the clotting system in ARDS results from enhanced activation and propagation of clot formation together with suppression of fibrinolysis, ${ }^{7-9}$ and is thought to be mediated by dysfunction of the pulmonary endothelium in the case of influenza A. ${ }^{10}$ Targeting the coagulation and fibrinolytic systems to improve the treatment of ARDS has been proposed since at least 2003. ${ }^{11-14}$ In particular, the use of plasminogen activators to limit ARDS progression and reduce ARDS-induced death has received strong support from animal models ${ }^{15-17}$ and a phase 1 human clinical trial. In 2001,

Submitted: March 18, 2020, Accepted: March 18, 2020, Published online: March 20,2020 .

From the Department of Surgery (H.B.M., E.E.M., R.C.M.), University of Colorado Denver, Denver, Colorado; Koch Institute for Integrative Cancer Research, Center for Precision Cancer Medicine, Departments of Biological Engineering and Biology (C.D.B., M.B.Y.), Massachusetts Institute of Technology, Cambridge; Division of Acute Care Surgery, Trauma and Surgical Critical Care, Department of Surgery (C.D.B., M.B.Y.), Beth Israel Deaconess Medical Center, Harvard Medical School, Boston, Massachusetts; Department of Surgery (E.E.M.), Ernest E Moore Shock Trauma Center at Denver Health; Department of Medicine (P.K.M.), University of Colorado Denver, Denver, Colorado; Department of Anesthesia, Critical Care and Pain Medicine (D.S.T.), Beth Israel Deaconess Medical Center, Harvard Medical School, Boston, Massachusetts; and Department of Surgery (F.A.M.), University of Florida, Gainesville, Florida.

This is an open-access article distributed under the terms of the Creative Commons Attribution-Non Commercial-No Derivatives License 4.0 (CCBY-NC-ND), where it is permissible to download and share the work provided it is properly cited. The work cannot be changed in any way or used commercially without permission from the journal.

Address for reprints: Michael B. Yaffe, MD, PhD, Koch Institute for Integrative Cancer Research, Center for Precision Cancer, Medicine, Departments of Biological Engineering and Biology, Massachusetts Institute of Technology, Cambridge, MA; email: myaffe@mit.edu.

DOI: 10.1097/TA.0000000000002694
Hardaway and colleagues ${ }^{18}$ showed that administration of either urokinase or streptokinase to patients with terminal ARDS reduced the expected mortality from $100 \%$ to $70 \%$ with no adverse bleeding events. Importantly, the majority of patients who ultimately succumbed died from renal or hepatic failure, rather than pulmonary failure.

A recent American Hospital Association assessment indicates that up to 960,000 patients may require mechanical ventilation, for which only 62,000 fully-featured ventilators are currently available, based on a 2009 survey. ${ }^{19}$ The estimated mortality rate for critically ill patients infected with COVID-19 is $22 \%$ to $64 \%$, using statistics from early reports from Hubei Province. $18,20,21$ Taken together, these statistics indicate an emergent need for effective therapeutics to treat and attenuate ARDS secondary to COVID-19 and, particularly, to salvage patients who have decompensating respiratory status but no access to a mechanical ventilator or extracorporeal membrane oxygenation (ECMO). We posit that administration of tissue plasminogen activator (tPA), as a compassionate salvage approach, may have merit in this situation.

Consideration of therapies that are widely available but not recognized for this indication and traditionally considered "high-risk," such as fibrinolytic agents, is warranted in this unprecedented public health emergency, since the risk of adverse events from tPA is far outweighed by the certainty of death in patients meeting the eligibility criteria for this treatment. While the prior study by Hardaway et al. evaluating fibrinolytic therapy for treatment of ARDS used urokinase and streptokinase, the more contemporary approach to thrombolytic therapy involves the use of tPA due to higher efficacy of clot lysis with comparable bleeding risk to the other fibrinolytic agents. In addition, tPA treatment was reported to have a greater reduction of death, a larger increase in arterial $\mathrm{PO}_{2}$ and a larger decrease in arterial $\mathrm{PCO}_{2}$, compared with untreated controls, than either urokinase-plasminogen activator (uPA) or plasmin in a comprehensive meta-analysis of animal studies of acute lung injury, although none of those studies included viral-induced ARDS. ${ }^{16}$

The dose, route of administration, and duration of treatment remain to be defined, but modeling efforts by individuals interested in this approach are both needed and underway. In animal models of acute lung injury, intratracheal and intravenous dosing of fibrinolytic agents was more effective than nebulized delivery. Based on a large body of experience using tPA for acute treatment of strokes and myocardial infarctions, ${ }^{22,23}$ intravenous 
administration may be the easiest to implement. However, unlike the brief treatment used in those situations where a defined nidus of clot is present without ongoing widespread disruption of the hemostatic system, we believe an initial approach might be to administer $25 \mathrm{mg}$ of tPA over 2 hours followed by a $25-\mathrm{mg}$ tPA infusion administered over the subsequent 22 hours, with a dose not to exceed $0.9 \mathrm{mg} / \mathrm{kg}$. The same exclusion criteria currently in place for stroke and MI treatment could be used, with responders maintained for some period on a heparin infusion after completion of the tPA treatment. Exactly which patients would qualify for this salvage treatment similarly remains to be defined, but patients with COVID-19-induced ARDS who have a pO2/FiO2 ratio less than 60 and a $\mathrm{PCO}_{2}$ greater than 60 despite prone positioning and maximal mechanical ventilatory support would seem to be ideal candidates, particularly in settings where ECMO is not a possibility. Furthermore, in scenarios where there is no further mechanical ventilation capacity, this may be appropriate for those with progressive pulmonary deterioration.

Extraordinary times may call for extraordinary measures. If an observational trial of this treatment in the first series of patients is effective and safe, the approach could be readily broadened. This would have multiple patient-related and public health benefits including: (1) earlier weaning from the ventilator to free up more ventilators for other patients in need; (2) preventing patients from progressing to a need for ECMO support, which is likely to be limited in a resource-limited crisis; and (3) leveraging the availability, modest cost, and wide preexisting clinical familiarity with tPA.

\section{DISCLOSURE}

The authors declare no conflicts of interest.

\section{ACKNOWLEDGMENTS}

This work was supported by NIH Grants UM1-HL120877 (EEM, MBY), F32-HL134244 (CDB), and L30-GM120751 (CDB); and DoD Peer Reviewed Medical Research Program, Contract Number W81XWH-161-0464 (MBY).

\section{REFERENCES}

1. https://spiral.imperial.ac.uk/bitstream/10044/1/77482/5/Imperial\%20College \%20COVID19\%20NPI\%20modelling\%2016-03-2020.pdf. Accessed 3/17/2020.

2. Acute Respiratory Distress Syndrome Network, Brower RG, Matthay MA, Morris A, Schoenfeld D, Thompson BT, Wheeler A. Ventilation with lower tidal volumes as compared with traditional tidal volumes for acute lung injury and the acute respiratory distress syndrome. $N$ Engl J Med. 2000;342(18):1301-1308.

3. Bone RC, Francis PB, Pierce AK. Intravascular coagulation associated with the adult respiratory distress syndrome. Am J Med. 1976;61(5):585-589.

4. Ware LB. Pathophysiology of acute lung injury and the acute respiratory distress syndrome. Semin Respir Crit Care Med. 2006;27(4):337-349.
5. Ware LB, Matthay MA. The acute respiratory distress syndrome. $N$ Engl J Med. 2000;342(18):1334-1349.

6. Tian S, Hu W, Niu L, Liu H, Xu H, Xiao SY. Pulmonary pathology of earlyphase 2019 novel coronavirus (COVID-19) pneumonia in two patients with lung cancer. J Thorac Oncol. 2020. pii: S1556-0864(20)30132-5.

7. Bastarache JA, Ware LB, Bernard GR. The role of the coagulation cascade in the continuum of sepsis and acute lung injury and acute respiratory distress syndrome. Semin Respir Crit Care Med. 2006;27(4):365-376.

8. Gunther A, Mosavi P, Heinemann S, Ruppert C, Muth H, Markart P, Grimminger F, Walmrath D, Temmesfeld-Wollbruck B, Seeger W. Alveolar fibrin formation caused by enhanced procoagulant and depressed fibrinolytic capacities in severe pneumonia. Comparison with the acute respiratory distress syndrome. Am J Respir Crit Care Med. 2000;161(2 Pt 1):454-462.

9. Ware LB, Bastarache JA, Wang L. Coagulation and fibrinolysis in human acute lung injury-new therapeutic targets? Keio J Med. 2005;54(3): 142-149.

10. Yang Y, Tang H. Aberrant coagulation causes a hyper-inflammatory response in severe influenza pneumonia. Cell Mol Immunol. 2016;13(4): 432-442.

11. Laterre PF, Wittebole X, Dhainaut JF. Anticoagulant therapy in acute lung injury. Crit Care Med. 2003;31(Suppl 4):S329-S336.

12. MacLaren R, Stringer KA. Emerging role of anticoagulants and fibrinolytics in the treatment of acute respiratory distress syndrome. Pharmacotherapy. 2007;27(6):860-873.

13. Schultz MJ, Haitsma JJ, Zhang H, Slutsky AS. Pulmonary coagulopathy as a new target in therapeutic studies of acute lung injury or pneumonia - a review. Crit Care Med. 2006;34(3):871-877.

14. Ware LB, Camerer E, Welty-Wolf K, Schultz MJ, Matthay MA. Bench to bedside: targeting coagulation and fibrinolysis in acute lung injury. $\mathrm{Am} \mathrm{J}$ Physiol Lung Cell Mol Physiol. 2006;291(3):L307-L311.

15. Hardaway RM, Williams CH, Marvasti M, Farias M, Tseng A, Pinon I, Yanez D, Martinez M, Navar J. Prevention of adult respiratory distress syndrome with plasminogen activator in pigs. Crit Care Med. 1990;18(12): 1413-1418.

16. Stringer KA, Hybertson BM, Cho OJ, Cohen Z, Repine JE. Tissue plasminogen activator (tPA) inhibits interleukin-1 induced acute lung leak. Free Radic Biol Med. 1998;25(2):184-188.

17. Liu C, Ma Y, Su Z, et al. Meta-analysis of preclinical studies of fibrinolytic therapy for acute lung injury. Front Immunol. 2018;9:1898.

18. Hardaway RM, Harke H, Tyroch AH, Williams CH, Vazquez Y, Krause GF. Treatment of severe acute respiratory distress syndrome: a final report on a phase I study. Am Surg. 2001;67(4):377-382.

19. https://sccm.org/Blog/March-2020/United-States-Resource-Availability-forCOVID-19. Accessed 3/17/2020.

20. Wang D, Hu B, Hu C, et al. Clinical characteristics of 138 hospitalized patients with 2019 novel coronavirus-infected pneumonia in Wuhan, China. JAMA. 2020;323:1061.

21. Yang X, Yu Y, Xu J, et al. Clinical course and outcomes of critically ill patients with SARS-CoV-2 pneumonia in Wuhan, China: a single-centered, retrospective, observational study. Lancet Respir Med. 2020. pii: S2213-2600 (20)30079-5

22. Kaufman C, Kinney T, Quencer K. Practice trends of fibrinogen monitoring in thrombolysis. J Clin Med. 2018;7(5). pii: E111.

23. Wardlaw JM, Murray V, Berge E, del Zoppo GJ. Thrombolysis for acute ischaemic stroke. Cochrane Database Syst Rev. 2014;7:CD000213. 